\title{
Genetic parameter estimation to milk yield and fat and protein yield deviated from $3 \%$ of concentration in milk, in dairy herds of southern Chile
}

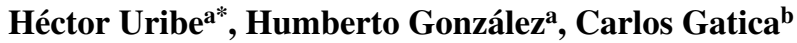

\begin{abstract}
Chilean milk processing industry is providing clear signs to milk farmers regarding the significant importance of milk solids within raw milk payment schemes. A litre of milk containing 3\% of fat and $3 \%$ of protein is defined as a basic litre and, each additional kilo of fat and/or protein receives an extra payment. These are new production traits which must be researched on. In this study, 64,029 lactations, on 24 Región de Los Ríos at Southern of Chile herds, were used. Genetic parameters for milk yield and fat and protein above $3 \%$ yield were estimated. A multiple trait linear model, solved by BLUP methodology, was used. Variance components were estimated using AIREMLF90 and VCE software. Estimated heritability for milk yield, and fat and protein above $3 \%$ yield were $0.16 \pm 0.004,0.44 \pm 0.007$ and $0.42 \pm 0.006$, respectively. Estimated genetic correlations were -0.285 and -0.331 between milk yield and fat and protein above $3 \%$ yield, respectively. It is concluded that there exist genetic variation for the two new traits proposed by the Chilean milk processing industry and, genetic selection for these traits should be done based on their estimated breeding values. However these two traits, plus milk yield, should be included in a selection index to account for the negative genetic correlations among them and minimise selection against milk yield.
\end{abstract}

Key words: genetic improvement, milk solids.

RESUMEN. En Chile la industria está dando señales claras al productor lechero al otorgar una importante ponderación al contenido de sólidos lácteos en la determinación del precio de la leche cruda. Para este efecto se definió como "litro base" a un litro de leche con contenidos de 3,0\% de grasa y 3,0\% de proteína. Sobre dicha base, cada kilogramo de ambos sólidos recibe una valoración adicional, constituyéndose así nuevas características composicionales que deben ser estudiadas. En este estudio se estimaron parámetros genéticos para producción de leche y producción de grasa y proteína sobre 3\% de concentración en leche, a partir de 64.029 lactancias provenientes de 24 rebaños de la Región de Los Ríos en el sur de Chile. Se utilizó un modelo mixto multivariado resuelto con metodología BLUP. Los componentes de varianza fueron estimados usando los programas computacionales AIREMLF90 y VCE. Las heredabilidades estimadas para volumen de leche y producción de grasa y proteína sobre el $3,0 \%$ fueron $0,16 \pm 0,004,0,44 \pm 0,007$ y $0,42 \pm 0,006$, respectivamente. Las correlaciones genéticas entre producción de leche y producción de grasa y proteína sobre 3\% fueron $-0,285,-0,331$, respectivamente. Se concluye que existe variabilidad genética para las dos nuevas características creadas por la industria compradora de leche y que la selección genética debería hacerse basada en valores genéticos estimados para estas.

Palabras clave: mejoramiento genético, sólidos, leche.

\section{INTRODUCTION}

Seventy percent of industrialised Chilean milk is produced in the southern area of the country. The most important dairy production regions are Araucanía, Los Lagos and Los Ríos (Lerdón et al 2010). In these regions, milk production is mainly based on grazing pasture where the goal is to obtain high production of milk and milk solids per unit of land (González-Verdugo et al 2004).

There are some similarities between the dairy pastoral systems of New Zealand and southern Chile. As in New Zealand, the economic success of the Chilean dairy farmer is continuously being more dependent on milk solids output per unit of land rather than milk yield per cow (Delgadillo et al 2016).

The main factors influencing economic return of the dairy farmers are: 1) litres (L) containing 3.0\% weight/ volume $(\mathrm{w} / \mathrm{v})$ of fat and $3.0 \% \mathrm{w} / \mathrm{v}$ of protein, which is

Accepted: 13.03.2017.

aDepartamento de Producción Animal, Facultad de Ciencias Agronómicas, Universidad de Chile, Santiago, Chile.

${ }^{\mathrm{b}}$ CIA-CENEREMA, Facultad de Ciencias Veterinarias, Universidad Austral de Chile, Valdivia, Chile.

* Corresponding author: H Uribe; hector.a.uribe@gmail.com known as a standardised litre of milk (LB); 2) kilogram (kg) of fat above $3.0 \% \mathrm{w} / \mathrm{v}$ in each $\mathrm{L}$ of LB and, 3) $\mathrm{kg}$ of protein above $3.0 \% \mathrm{w} / \mathrm{v}$ in each $\mathrm{L}$ of $\mathrm{LB}$. The payment scheme of the industry for raw milk is highly influenced by these three factors (PROLESUR) ${ }^{1}$.

Considering the importance of milk solids concentration in the value of the raw milk and as part of its "Strategies for a Competitive Development of the Chilean Dairy Sector 2010-2020" document, the Milk Consortium S. A. ${ }^{2}$ outlined a production blueprint to be followed by the dairy sector. One of the goals indicated by the Milk Consortium was to increase the national average milk fat and protein concentration from $7.1 \%$ in 2010 to $7.6 \%$ in 2020 . Improvement of traits, such as fat and protein yield, can effectively be reached by genetic improvement programs, where selection

1 Prolesur. 2014. Resumen de Pauta de Pago de leche para la compra que PROLESUR realiza a los actuales productores de leche de la X Región de Los Lagos, continental. Vigencia: Desde el 1 de septiembre de 2014. Accessed on September 14, 2016; http://www.prolesur.cl/ component/docman/doc_download/249-pauta-de-precios-lechecruda-X-continental-sept-14 .

2 Consorcio Lechero, 2010. Estrategia de desarrollo competitivo del sector lácteo chileno, 2010-2020. Accessed on September 14, 2016; http://www.consorciolechero.cl/chile/docs/Estrategia-Desarrollo-Sectorial-2010-2020.pdf 
based on estimated breeding values would be an essential tool to choose the best breeding stock. Unfortunately the Chilean dairy sector does not have in place a national or regional dairy genetic improvement program where official estimation of additive genetic values can be done, and the Chilean dairy farmers depend on breeding value estimation done abroad for purchasing of breeding stock. Therefore the farmer is exposed to choose among several artificial insemination sire catalogs from different populations and estimation methodologies.

A second but not permanent way to increase milk solids is through improvement in management practices. Genetic improvement has the advantage of being accumulative; however, genetic parameters are needed to estimate reliable additive genetic merit of the population under an improvement genetic program.

According to the current Chilean raw milk payment scheme, a $\mathrm{kg}$ of milk protein above $3.0 \%$, is valued at almost 5 times higher than a $\mathrm{kg}$ of milk fat above $3.0 \%$ hence new traits which are milk fat and protein deviated from $3.0 \%$ may be worthwhile to explore as selection criteria. Dairy sire frozen semen catalogs provide genetic information on milk fat and protein yield and percentage but no on milk fat and protein departing from $3.0 \%$ concentration. Therefore Chilean dairy farmers have no genetic information on traits which are continuously gaining importance in the final price received by the milk that they produce.

Genetic parameter estimations for milk and milk fat and protein, in different dairy cattle breeds, are abundant on the literature; however, the new traits that arise from the particular Chilean raw milk payment scheme, which are a blending of solids yield and concentration, have not been researched.

The final purpose of this work was to estimate (co) variance components for milk yield and fat and protein yield deviated from $3 \%$ of concentration in milk.

\section{MATERIAL AND METHODS}

DATA

The raw data set had information on 64,029 complete lactation records taken on 24 farms of the Región de Los Ríos, southern of Chile, from 1994 to 2014. Milk yields came already adjusted by the milk recording agency to 305 days of lactation. Fat and protein deviations were calculated by subtracting 3.0 to the original percentage of both, and multiplying this result by corresponding kilograms of raw milk; hence the new traits blended milk volume and concentration of milk solids. The third trait included in the analysis was milk yield measured in kilograms. As part of data editing, yield observations, in any of the three traits, below or above three standard deviations from the raw mean were considered outliers and deleted from the data set. Also, to minimise difficulties on variance components estimation convergence the herd, year and season interaction subclasses that had less than five observations were deleted from de data set. The final data set had 62,532 lactations on 23,505 cows; through the pedigree file it was possible to include in the analyses a total of 27,244 animals.

\section{STATISTICAL MODEL}

The data were analysed using a multivariate three traits animal model solved by best linear unbiased prediction (BLUP), (Henderson 1984). Yields variables (milk, fat and protein) were all identically modeled as function of herd, year of calving, season of calving, parity number, animal and permanent environmental effect. The interaction among herd, year and season of production was treated as a random effect in the model as well as the animal genetics and permanent environmental effects. Parity number was treated as a fixed effect. The statistical model for each trait was:

$$
y_{i j k l}=\mu+L_{i}+H_{j}+a_{i j k}+p_{i j k}+e_{i j k l}
$$

Where:

$y_{i j k l}=$ is a phenotypic record on one of the three yield traits above described.

$\mu=$ is the population mean.

$L_{i}=$ is the fixed effect of the $\mathrm{i}^{\text {th }}$ parity number.

$H_{j}=$ is the random effect of the $\mathrm{j}^{\text {th }}$ herd, year and season interaction $\sim \mathrm{N}\left(0, \mathrm{I} \sigma_{h}^{2}\right)$.

$a_{i j k}=$ is the random additive genetic effect of the $i \mathrm{jk}^{\text {th }}$ animal for each of the three yield traits $\sim \mathrm{N}\left(0, \mathrm{~A} \sigma_{a}^{2}\right)$.

$p_{i j k}=$ is the random permanent environment effect of the $\mathrm{ijk}^{\text {th }}$ animal for each of the three yield traits $\sim \mathrm{N}\left(0, \mathrm{I} \sigma_{p e}^{2}\right)$. $e_{i j k l}=$ is the random residual error of the $\mathrm{ijk}^{\text {th }}$ phenotypic record $\sim \mathrm{N}\left(0, \mathrm{I} \sigma_{e}^{2}\right)$.

$\sigma_{\mathrm{h}}^{2}, \sigma_{a}^{2}, \sigma_{p e}^{2}$ and $\sigma_{e}^{2}$ are herd-year-season, additive genetic, permanent environmental and residual variances, respectively.

The (co)variance structure of the model was:

$$
\operatorname{Var}\left(\begin{array}{c}
a \\
p e \\
h \\
e
\end{array}\right)=\left(\begin{array}{cccc}
G & 0 & 0 & 0 \\
0 & P e & 0 & 0 \\
0 & 0 & H & 0 \\
0 & 0 & 0 & E
\end{array}\right)
$$

Where:

$$
G=\left(\begin{array}{ccc}
A \sigma_{a_{1}}^{2} & A \sigma_{a_{1,2}} & A \sigma_{a_{1,3}} \\
A \sigma_{a_{2,1}} & A \sigma_{a_{2}}^{2} & A \sigma_{a_{2,3}} \\
A \sigma_{a_{3,1}} & A \sigma_{a_{3,2}} & A \sigma_{a_{3}}^{2}
\end{array}\right),
$$




$$
\begin{gathered}
P e=\left(\begin{array}{ccc}
I_{1} \sigma_{p e_{1}}^{2} & I_{1} \sigma_{p e_{1.2}} & I_{1} \sigma_{p e_{1,3}} \\
I_{1} \sigma_{p e_{2.1}} & I_{1} \sigma_{p e_{2}}^{2} & I_{1} \sigma_{p e_{2,3}} \\
I_{1} \sigma_{p e_{3,1}} & I_{1} \sigma_{p e_{3,2}} & I_{1} \sigma_{e p_{3}}^{2}
\end{array}\right), \\
H=\left(\begin{array}{ccc}
I_{2} \sigma_{h_{1}}^{2} & I_{2} \sigma_{h_{1.2}} & I_{2} \sigma_{h_{1.3}} \\
I_{2} \sigma_{h_{2,1}} & I_{2} \sigma_{h_{2}}^{2} & I_{2} \sigma_{h_{2,3}} \\
I_{2} \sigma_{h_{3,1}} & I_{2} \sigma_{h_{3,2}} & I_{2} \sigma_{h_{2}}^{2}
\end{array}\right) \\
\text { and } E=\left(\begin{array}{ccc}
I_{3} \sigma_{e_{1}}^{2} & I_{3} \sigma_{e_{1,2}} & I_{3} \sigma_{e_{1,3}} \\
I_{3} \sigma_{e_{2,1}} & I_{3} \sigma_{e_{2}}^{2} & I_{3} \sigma_{e_{2,3}} \\
I_{3} \sigma_{e_{3,1}} & I_{3} \sigma_{e_{3,2}} & I_{3} \sigma_{e_{3}}^{2}
\end{array}\right)
\end{gathered}
$$

Where: $A=$ is the additive genetic relationship matrix among all animals found in the pedigree file, $\sigma_{a_{i}}^{2}=$ is the additive genetic variance for the $i^{\text {th }}$ yield trait, $\sigma_{a_{i, j}}=$ is the additive genetic covariance between the $i^{\text {th }}$ and $j^{\text {th }}$ yield traits, $I_{1}=$ is an identity matrix of size equal to the number of animals with records $(23,505), I_{2}=$ is an identity matrix of size equal to the number of herd, year and season interactions (601), $I_{3}=$ is an identity matrix of size equal to the number of observations $(62,532), \sigma_{\mathrm{pe}_{i}}^{2}=$ is the permanent environmental variance for the $i^{\text {th }}$ yield trait, $\sigma_{p e_{i, j}}=$ is the permanent environmental covariance between the $i^{\text {th }}$ and $j^{\text {th }}$ yield traits, $\sigma_{\mathrm{h}_{i}}^{2}=$ is the herd, year and season interaction variance for the $i^{\text {th }}$ yield trait, $\sigma_{h_{i, j}}=$ is the herd, year and season interaction covariance between the $i^{t h}$ and $j^{\text {th }}$ yield traits, $\sigma_{e_{i}}^{2}=$ is the residual variance for the $i^{t h}$ yield trait, $\sigma_{e_{i, j}}=$ is the residual covariance between the $i^{\text {th }}$ and $j^{\text {th }}$ yield traits.

The final multivariate model had 154,071 equations to be solved. The variance components were estimated by restricted maximum likelihood (Patterson and Thompson 1971) using VCE ${ }^{3}$ and AIREMLF90 (Misztal et al 2002) software.

3 Kovac M, Groeneveld E. 2003. VCE 5. User's guide and reference, Manual. Version 5.1. Available at http://vce.tzv.fal.de/manual/index. html.

\section{RESULTS}

Overall raw means, standard deviations, minimum and maximum values of the three traits are presented in table 1 . Yield deviation from $3 \%$ can be negative when a particular cow has a concentration of fat or protein below $3 \%$ which was the case in some of the cows in this data set. After data editing and deleting outliers the variation of fat yield deviated from $3 \%$ of concentration was between $+217 \%$ and $-214 \%$ regarding the average $(51.09 \mathrm{~kg})$. Protein yield deviated from $3 \%$ of concentration in milk moved from $-253 \%$ to $+252 \%$ regarding the average $(22.5 \mathrm{~kg})$. These results (table 1) show the large variation that exists for both fat and protein yield deviated from 3\% of concentration.

Milk yield average was 7,606 $\pm 1,670 \mathrm{~kg}$ and ranged from 2,468 to $12,819 \mathrm{~kg}$ per lactation which reflects a great phenotypic variability.

The mixed model equations took 245 rounds to reach the convergence criterion which, in the software parameter program, was previously set at $1.0 \times 10^{-7}$. Table 2 shows genetic, permanent environmental, herd-year-season, residual and phenotypic estimated variances, and heritability for the three traits. Phenotypic variance was the sum of the genetic, permanent environmental, herd-year-season and residual estimated variances.

Heritability estimates of milk fat and protein, deviated from $3 \%$, yield were $0.44 \pm 0.007$ and $0.42 \pm 0.006$, respectively (table 2 ).

Table 3 shows the estimates of genetic and phenotypic correlations for milk yield and fat and protein deviated from $3 \%$ yield. At the genetic level milk yield was negatively correlated with fat and protein yield deviated from $3 \%$ of concentration in milk, the correlation coefficients were found at -0.285 and -0.331 between milk yield and fat and protein, respectively.

Phenotypic correlations found in this study were low among milk yield and fat and protein above $3 \%$ yield (table 3 ), and medium between fat and protein yield $(0,410)$.

\section{DISCUSSION}

Elzo et al (2004), using records of 56,277 first lactation cows, found a milk yield mean similar to that found

Table 1. Means, standard deviations and minimum and maximum values of milk yield and fat and protein yield deviated from $3 \%$ of concentration in milk.

\begin{tabular}{lcccc}
\hline & Mean $^{1}$ & Standard Deviation & Minimum & Maximum \\
\hline Milk* & 7,606 & 1,670 & 2,468 & 12,819 \\
Fat* & 51.09 & 34.35 & -57.99 & 161.95 \\
Protein* & 22.25 & 17.66 & -34.00 & 78.99 \\
\hline
\end{tabular}

$*=\mathrm{kg} .{ }^{1}=62,532$ lactations 
Table 2. Estimates of genetic $\left(\sigma_{a}^{2}\right)$, permanent environmental $\left(\sigma_{p e}^{2}\right)$, herd-year-season $\left(\sigma_{h}^{2}\right)$, residual $\left(\sigma_{e}^{2}\right)$ and phenotypic $\left(\sigma_{P}^{2}\right)$ variances, and heritability $\left(h^{2}\right)$ of milk yield and fat and protein yield deviated from $3 \%$ of concentration in milk.

\begin{tabular}{lcccccc}
\hline Trait & $\left(\sigma_{a}^{2}\right)$, & $\left(\sigma_{p e}^{2}\right)$, & $\left(\sigma_{h}^{2}\right)$, & $\left(\sigma_{e}^{2}\right)$ & $\left(\sigma_{P}^{2}\right)$ & $h^{2} \pm s e$ \\
\hline Milk & 428,540 & 372,950 & $1,185,700$ & 761,180 & $2,748,370$ & $0.16 \pm 0.004$ \\
Fat $^{*}$ & 513.54 & 188.57 & 207.65 & 248.12 & $1,157.88$ & $0.44 \pm 0.007$ \\
Protein $^{*}$ & 120,87 & 42.43 & 74.20 & 52.48 & 289.99 & $0.42 \pm 0.006$ \\
\hline
\end{tabular}

$*=\mathrm{kg}$ deviated from $3 \%$ of concentration in milk. $h^{2}$ estimated as $\sigma_{a}^{2} / \sigma_{a}^{2}+\sigma_{p e}^{2}+\sigma_{h}^{2}+\sigma_{e}^{2}$

Table 3. Estimates of genetic (above the diagonal) and phenotypic (below the diagonal) correlations between milk yield and fat and protein yield deviated from $3 \%$ of concentration in milk.

\begin{tabular}{llll}
\hline & Milk & Fat & Protein \\
\hline Milk & ---- & -0.285 & -0.331 \\
Fat & 0.044 & ---- & 0.626 \\
Protein & 0.039 & 0.410 & ---- \\
\hline
\end{tabular}

here $(7,502 \pm 1,829)$; their data, analysed considering the multibreed makeup of the population, were gathered from 1990 to 2000 in southern Chile. Montaldo et al (2015), researching GxE interaction between US and Chilean sire performance, analysed 243,134 Chilean cow lactations gathered from 1997 to 2008, and found that the average milk yield was $8,082 \mathrm{~kg}$ per lactation. Smaller milk yield average $(4,503 \mathrm{~kg})$ was reported by Lembeye et al (2016b) working with 57,018 records of New Zealand Holstein cows milked twice daily; although direct comparison between these results is not straightforward due to the fact that New Zealand milk production is seasonal, having less days in milk, while dairy production in southern Chile relays on medium to high concentrate input. Uribe and Smulders (2004) found an average milk yield of $5,044 \mathrm{~kg}$ in a sample of 3,837 lactations in Overo Colorado cattle from 16 dairy herds in southern Chile.

Heritability estimate for milk yield was $0.16 \pm 0.004$ which is in the low range of previous estimates found in the literature for this trait. This heritability estimate is similar to that reported by Lembeye et al $\left(2016^{\mathrm{a}}\right)$ for low producing New Zealand cows milked once-a-day $(0.18 \pm 0.02)$. The estimated heritability of Montaldo et al (2015) for the same trait in Chilean cows was $0.19 \pm 0.006$ which is slightly superior to that found in this research. Uribe and Smulders (2004) found that heritability of milk yield for Chilean Overo Colorado cattle was 0.25 , which is also higher than the estimated heritability reported in this study. However, Sneddon et al (2015) analysing 15,366 test day records of 4,378 New Zealand cows born in 2009 reported a hereditability estimate of 0.19 , which is closer to the heritability reported in this study. Higher heritability estimates, for milk yield, were found by Lembeye et al $\left(2016^{\mathrm{b}}\right)$ they were at 0.33 and 0.36 for once- and twice-a-day milking cows, respectively. Elzo et al (2004) reported heritability estimates, for milk yield, ranging from 0.31 to 0.34 among the Chilean breeds included in their data set; in their research estimates of genetic variance were similar to that found in this research (table 2) but higher than those reported by Lembeye et al $\left(2016^{\mathrm{b}}\right)$ which were 90,445 and 163,396 for once- and twice-a-day milking cows, respectively. Heritability estimates change among studies due to several reasons, being the most important the type of data and the statistical model. Also in developed countries, where milking cows are kept inside barns and fed using total mixed ration, the environmental variation across herd is lower yielding higher heritability estimates.

Heritability estimates of milk fat and protein yield deviated from $3 \%$ of concentration were $0.44 \pm 0.007$ and $0.42 \pm 0.006$, respectively (table 2 ), these are similar to the estimates of Uribe and Smulders (2004), for fat and protein percentage in Overo Colorado cattle, 0.44 and 0.43 , respectively. These results are very close to the average between estimates of Lembeye et al $\left(2016^{\mathrm{b}}\right)$ for fat and protein yield $(0.25 \pm 0.010)$, and fat and protein percentage (0.66 \pm 0.009$)$. Sneddon et al (2015) found heritabilities, for fat and protein percentage, at $0.35 \pm 0.05$ and $0.32 \pm 0.05$, respectively, which are lower than the estimates presented in this research. The estimates of Elzo et al (2004) for fat and protein yield in Chilean cows ranged from 0.29 to 0.37 and 0.17 and 0.24 , respectively. Higher heritabilities were estimated by Montaldo et al (2015) which were $0.55 \pm 0.007$ for both fat and protein percentage. Estimations of heritability for solids traits yield deviated from a given concentration in milk were not found in the literature. Although the fat and protein traits reviewed here and reported by previous researchers are not exactly the same as the ones used in this work, it seems that fat and 
protein yield deviated from $3 \%$ of concentration in milk follow similar behaviour for fat and protein percentage; this may help to explain the higher heritability of fat and protein yield deviated from $3 \%$ of concentration in milk, when compared to fat and protein yields.

Genetic correlations among milk yield and milk solids yield has been usually found positive and high (Elzo et al 2004, Lembeye et al 2016a,b, Sneddon et al 2015) however, genetic correlations among milk yield and milk solids percentage have been found negative (Lembeye et al 2016 Sneddon et al 2015). In this work the correlations among fat and protein yield, deviated from $3 \%$ of concentration in milk, and milk yield were negative (table 3), these findings might indicate that the behavior of the traits analysed here is closer to solids concentration than to solids yield.

Phenotypic correlations found in this study (table 3) are much different than those of Sneddon et al (2015) who reported phenotypic correlations among milk yield and fat and protein yield of 0.75 and 0.92 , respectively. Similar findings, for pure bred Holstein cows, were reported by Elzo et al (2004) where the correlations, in the same order, were estimated at 0.82 and 0.88 . The estimates of Lembeye et al $\left(2016^{\mathrm{b}}\right)$, for the same traits, were also high and positive, 0.68 and 0.91 .

Chilean dairy farmers are facing a scenario where the weights put on the raw milk payment are shifting from volume to milk solids. The companies that buy raw milk in Chile, where 3 of them concentrate near to $70 \%$ of the total ${ }^{4}$, pay per $\mathrm{kg}$ of fat and protein above $3 \%$ of concentration in milk. However, the breeding decision of the farmer, at the time of choosing a particular sire, rely on the information provided by frozen semen sire catalogs elaborated in a different country. Hence estimated breeding values and selection indexes, provided in a particular catalog, do not directly apply to their production reality because, the information used to estimate genetic merit is from a different population and the economic scenario of production is also different. Moreover, the new traits created by the Chilean dairy processing industry (fat and protein yield deviated from $3 \%$ of concentration in milk) are not genetically evaluated somewhere else, hence would not be included in an imported selection index.

There are many reports in the literature concerning variance components estimation for milk traits. The studies discussed in this research were chosen because three of them were done using Chilean data (Uribe and Smulders 2004, Elzo et al 2004, Montaldo et al 2015), and the others were the newest ones and done in New Zealand (Lembeye et al 2016 ${ }^{\mathrm{a}, \mathrm{b}}$, Sneddon et al 2015); where dairy production rely on seasonal grows of pasture and grazing which is the case in south of Chile.

4 ODEPA, Oficina de Estudios y Políticas Agrarias, Ministerio de Agricultura. Chile. 2016. Boletín de la Leche: producción, recepción, precios y comercio exterior. Ministerio de Agricultura, Chile. Available at http://www.odepa.cl/wp-content/uploads/2016/08/ informe lacteo 062016.pdf
Kilograms of fat and protein deviated from $3 \%$ of concentration in milk are new traits that blend milk yield and milk solids concentration, therefore direct extrapolation of genetic parameters either from milk yield, fat and protein yield or fat and protein percentage might be not totally correct. Genetic correlations between milk yield and fat and protein yield deviated from $3 \%$ of concentration are both negative (table 3 ), which may become favorable in an economic scenario where farm gate milk payment allocates more weight to fat and protein and penalizes milk volume. However, under the current Chilean economic scenario, these negative correlations may lead that genetic selection for fat and protein yield above $3 \%$ of concentration would improve the price per litre of milk but decrease the total farmer income due to a reduction in the total volume of milk. Furthermore, the negative genetic correlations found in this work would indicate that fat and protein yields above $3 \%$ of concentration are highly dependent on milk fat and protein percentage therefore their genetic behavior is more similar to those traits than to milk fat and protein total yield.

Genetic variation in the new traits exist, heritability estimates for milk fat and protein yield deviated from $3 \%$ of concentration indicate that genetic selection for these traits must be effective to increase milk fat and protein output, provided that breeding values are estimated using data from the same population. Ideally, estimated breeding values of these traits should be blended into a Chilean selection index, in which the estimated breeding values for the new traits and milk yield are weighed according to their economic importance in a local scenario.

\section{REFERENCES}

Delgadillo J, González-Verdugo H, Uribe H. 2016. Genetic-economic comparison of New Zealand Holstein and Jersey-New Zealand Holstein cross under a pastoral scheme in southern Chile. Arch Med Vet 48, 261-267.

Elzo MA, Jara A, Barría N. 2004. Genetic parameters and trends in the Chilean multibreed dairy cattle population. J Dairy Sci 87, 1506-1518.

González-Verdugo H, Magofke JC, Mella C. 2004. Productivity, intake and biological efficiency in New Zealand Friesian and F1 (JerseyNew Zealand Friesian) cows calved during late winter in the Xth Region, Chile. Arch Med Vet 37, 37-47.

Henderson CR. 1984. Applications of Linear Models in Animal Breeding. University of Guelph, Guelph, Ontario, Canada.

Lembeye F, López-Villalobos N, Burke JL, Davis SR. 2016ª . Estimation of genetic parameters for milk yield traits at different herd production levels in cows milked once or twice daily in New Zealand. Proceeding of the New Zealand Society of Animal Production. 76, 49-53.

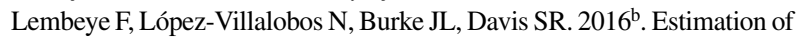
genetic parameters for milk traits in cows milked once- or twice-daily in New Zealand. Livest Sci 185, 142-147.

Lerdón J, Muñoz C, Moreira V. 2010. Productive and economic characterization of medium and large dairy farmers of southern Chile. IDESIA 28, 41-49.

Misztal I, Tsuruta S, Strabel T, Auvray B, Druet T, Lee D. 2002. BLUPF90 and related program (BGF90). Proc. $7^{\text {th }}$ World Congress on Genetics Applied to Livestock Production, Montpellier, France, CD-Rom Communication 28, Pp 1-7. 
Montaldo HH, Castillo-Juárez H, Lizana C, Trejo C, Cienfuegos-Rivas EG, Pelcastre-Cruz A. 2015. Genotype-environmental interaction between Chile and North America and between Chilean herd environmental categories for milk yield traits in Black and White cattle. Animal Science Papers and Reports, 33, 23-33.

Patterson HD, Thompson R. 1971. Recovery of inter-block information when the block sizes are unequal. Biometrika, 58, 545-555.
Sneddon NW, López-Villalobos N, Davis SR, Hickson RE, Shalloo L. 2015. Genetic parameters for milk components including lactose from test day records in the New Zealand dairy herd. New Zeal J Agr Res 58, 97-107.

Uribe HA, Smulders JP. 2004. Phenotypic, environmental and genetic parameters and trend estimation for milk production traits in Overo Colorado cattle. Arch Med Vet 36, 137-146. 